

\section{N I A}

Petroş

Târgu Ji

Drobeta-Turnu Severin

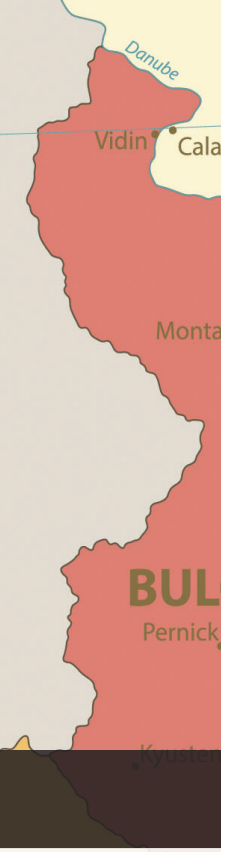

* Independent Researcher, Czech Republic

** Norwegian University of Science and Technology, Norway

Insight Turkey Vol. 21 / No. 2 / 2019, pp. 11-21

\title{
The Proposed Territorial Exchange between Serbia and Kosovo
}

\author{
ALEKSANDER ZDRAVKOVSKI* and SABRINA P. RAMET**
}

\begin{abstract}
Serbia and Kosovo have initiated a process of territorial exchange that could have serious repercussions, both in the Western Balkans and internationally. Historically speaking, territorial exchanges have a mixed record. In some instances, these projects have inaugurated periods of protracted cooperation and reconciliation. However, on a number of occasions, such agreements have had devastating consequences and have led to carnage, violence, and ethnic cleansing. Whereas Serbia and Kosovo have the sovereign and democratic right to engage in a genuine dialogue and decide on adjustments to their borders, it is important for the international community to pay close attention to the dynamics of the process and to consider the stability and security of the wider region should this project materialize.
\end{abstract}

\section{Vučić's Proposal}

n February 2018, former U.S. President Bill Clinton congratulated the people of Kosovo on the $10^{\text {th }}$ anniversary of their independence from Serbia. By way of a warning, he emphasized the fact that the youngest country in Europe needed to strengthen the rule of law and the protection of minorities. ${ }^{1}$ That same year in July, Serbian President Aleksandar Vučić reintroduced the old idea of an exchange of territories between his country and Kosovo. According to this scheme, Belgrade would acquire direct control over the northern part of Kosovo and, in return, Serbia would recognize the independence of its former autonomous province and compensate Pristina by ceding three towns in southern Serbia-Bujanovac, Medvedja, and Presevo- to Kosovo. Needless to say, Vučićs's proposal provoked a flurry of negative reactions, both internationally and domestically. In Kosovo, the plan has gained some traction with President Hashim Thaçi; on the other hand, Prime Minister Ramush Haradinaj and various opposition groups have vehemently opposed the idea, stating that such a land swap could trigger a local war. ${ }^{2}$ In Serbia, the plan was immediately rejected by the Serbian Orthodox Church and by nationalist parties such as the Serbian Radical Party and the Dveri Movement. Among Serbs, 
The $\mathbf{2 0 0 8}$ fait accompli of

Kosovo's independence forced

official Belgrade to engage in

negotiations with Prishtina that

had the aim of normalizing and

regulating relations between

the two countries provinces, Kosovo and Vojvodina. While the regime claimed that this move was intended to restore and assure security to the Serbs who were allegedly under threat from Albanians in Kosovo, the Serbian leader's real objective was to build his personal power, bolstering his preponderance within the collective presidency of Socialist Yugoslavia. With the help of the security apparatus, Milošević successfully crushed the largely peaceful ethnic Albanian resistance in Kosovo. ${ }^{5}$ The Albanian community responded by boycotting Serbian institutions, elections, censuses, etc. Serbian authorities showed their contempt for local Albanians, who constituted the majority of the province's population, by dismissing many Albanians from their posts, bringing in Serbian students to attend classes at the University of Pristina, renaming streets and public squares, and removing the names of Albanian heroes and replacing them with the names of Serbian heroes. The simmering conflict continued throughout the first part of the 1990s; it metastasized into a full-blown insurgency in 1998, when a group calling itself the Kosovo Liberation Army (KLA) launched an armed insurgency against Serbian security forces. ${ }^{6}$ Having no air-power and relying on old and inefficient weaponry, the Albanian insurgents were not able to sustain their initial momentum. However, in terms of drawing the attention of Western media and politicians to the Kosovo conflict, the KLA's rebellion was a resounding success. The atrocities of the Serbian security forces and the humanitarian crisis were covered in 


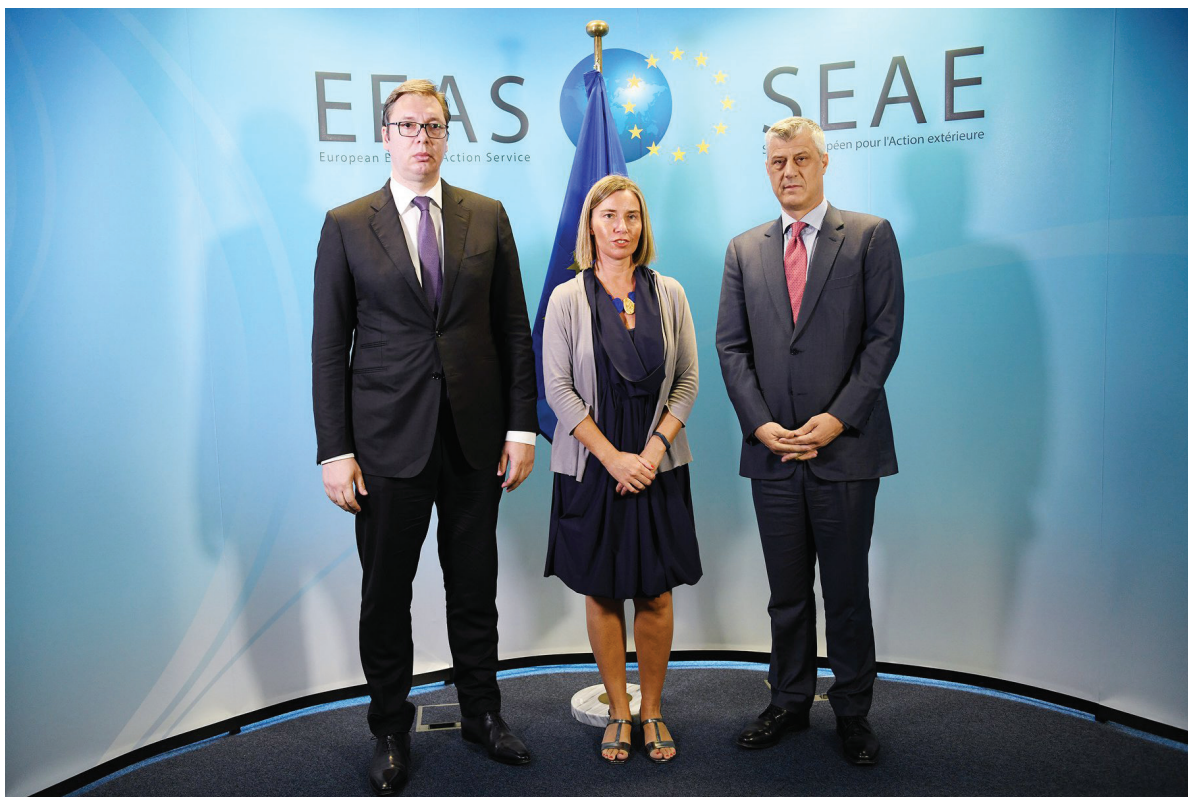

High Representative of the European Union for Foreign Affairs and Security Policy Mogherini (C), Kosovo President Thaçi (R) and Serbian President Vučić (L) pose for a photo during a meeting in Brussels on June 24, 2018.

much detail by Western media outlets and, as a consequence, pressure increased on Western governments to try to resolve the crisis diplomatically or, if necessary, by force. When thousands of Kosovo Albanians fled to North Macedonia, ${ }^{7}$ the crisis threatened to destabilize the Southern Balkans. After a number of diplomatic attempts failed to end the conflict, in March 1999 U.S. President Bill Clinton, with the backing of his British counterpart Tony Blair, decided to intervene directly by launching an air campaign against Serbia. ${ }^{8}$

The Serbian air-defense systems were no match for the NATO air force which repeatedly pounded Serbia, inflicting devastating blows to the military and civilian infrastructure of the country. Fearing a possible ground offensive, in June 1999 the government in Belgrade ceased all military activities in Kosovo and agreed to withdraw its security forces and political apparatus from Kosovo. The UN Security Council then passed resolution 1244, under the authority of which the United Nations Interim Administration Mission in Kosovo was created. Once Serbia withdrew its police, army, and other institutions from Kosovo, the province became de facto independent of Belgrade. This withdrawal brought with it an exodus of ethnic Serbs from Kosovo, along with members of some other ethnic minorities such as the Bosniaks and Roma who were subjected to pressure and harassment. ${ }^{9}$ In the northern part of Kosovo where ethnic Serbs form a majority of the population, however, Pristina has not been able to assert its authority, since Belgrade has continued to maintain a certain limited influence. Consequently, northern Kosovo became a no-man's land 
where crime, corruption, and nepotism reached levels that were unprecedented even by Balkan standards. ${ }^{10}$ The situation in the remaining part of Kosovo which was controlled by the UN was also dire. Economic hardships, lack of strategic planning, and corruption worsened the situation in the region. In March 2004, Kosovo was rocked by a number of incidents when ethnic Serbs were attacked and in some instances killed by mobs of Albanians. ${ }^{11}$ Only on February 17, 2008, after a number of political, legal, and economic reforms, and coordinating their move on a multilateral basis with Western powers, did the Kosovar authorities declare the independence of Kosovo from Serbia. While this move obtained the approval of most Western countries, including the U.S., the UK, France, and Germany, other states refused to accept this development, including Russia, China, India, Brazil, and several European countries with discontented ethnic minorities, specifically Spain, Greece, Cyprus, Romania, and Slovakia; the latter five countries joined Hungary, in 2018, in blocking Kosovo's admission to Interpol. A further blow to the Kosovar state came in 2010 when the Swiss politician, Dick Marty, published a groundbreaking report commissioned by the Council of Europe on the organ trafficking and inhumane treatment of Serbian prisoners of war by the KLA and its former leader and current president of the Republic, Hashim Thaçi. ${ }^{12}$ This report further weakened the position of Kosovo internationally and as a consequence, the process of recognition of the independence largely stalled.
Nevertheless, the 2008 fait accompli of Kosovo's independence forced official Belgrade to engage in negotiations with Pristina that had the aim of normalizing and regulating relations between the two countries. Although Serbia has not recognized the independence of Kosovo to date, the Serbian government and its then Prime Minister (currently Foreign Minister), Ivica Dačić, negotiated the normalization of relations with Kosovo's Prime Minister Hashim Thaçi in 2013. The negotiations were chaired by the High Representative of the European Union for Foreign Affairs and Security Policy, Catherine Ashton, in Brussels. Belgrade's main objective was to remove the parallel institutions in Kosovo and to iron out a legal framework that would improve the position of local Serbs. In addition, Belgrade hoped that this improvement in relations with Kosovo would enhance its prospects of eventual admission to the European Union. For its part, the government in Pristina engaged with Belgrade with the aim of showing that the Serbian government recognized the independence of Kosovo de facto by virtue of its negotiations with Pristina. Furthermore, this landmark agreement allowed Kosovo to commence with negotiations on the Stabilization and Association Agreement. After a number of grueling negotiations, the two sides concluded the agreement in April 2013. ${ }^{13}$

According to the agreement, a "Community of Serb Municipalities" was created in north Kosovo. However, the judicial institutions and police 
force were supposed to integrate with the Kosovar state. The first test came in December 2013 when elections were organized. Although the Serbian government appealed to the Serbs in north Kosovo to vote in the elections, the turnout was quite low -a mere 17 percent. Furthermore, there were many problems related to the acceptance of the mayoral posts in the four majority Serb municipalities in north Kosovo. The low turnout and general skepticism of the Serb population cast a serious doubt as to whether integration of this part of Kosovo with the official Kosovar institutions would ever be possible.

As of November 22, 2018, 109 of the world's 192 states have recognized the independence of Kosovo, which maintains 26 embassies and 14 consulates in other countries. Although the authorities in Pristina have managed to procure financial resources and to build impressive infrastructural projects in the country, the general outlook of the economy of Kosovo remains quite gloomy. Many young people from the country have expressed their desire to emigrate and settle in the West. ${ }^{14}$

\section{Territorial Exchanges: A Short History}

Dissolutions of complex federal states and processes of decolonization often entail bitter territorial disputes and, at times, armed conflicts. One of the most frequently studied examples is the break-up of the Soviet Union at the end of 1991. The Union

\section{The main incentive for} both Serbia and Kosovo

to come to an agreement on these territories is the understanding that this is a prerequisite for admission to the European Union

of Soviet Socialist Republics had a federal structure, but its constituent republics were only nominally autonomous. ${ }^{15}$ Sometimes, the boundaries between these entities did not align perfectly with the demographic and ethnic realities on the ground. As a consequence, during the break-up of the USSR, two conflicts erupted: between Armenia and Azerbaijan over Nagorno-Karabakh, which was inhabited by an Armenian majority population but was a part of the Azeri Republic, ${ }^{16}$ and between groups from the Garm and Gorno-Badakhshan areas of Tajikistan and the Tajik government, in which between 20,000 and 100,000 people are estimated to have lost their lives. Similarly, the dissolution of Socialist Yugoslavia provoked territorial disputes between Slovenia and Croatia over the Gulf of Piran, between Croatia and Montenegro over the Prevlaka peninsula, and between Serbia, Croatia, and Bosnia and Herzegovina over their borders.

The most praiseworthy example of a successful and peaceful territorial exchange in Europe involved an agreement between Slovakia and the 
The map shows the exchange of territory between Kosovo and Serbia as discussed by the leaders of the two countries.

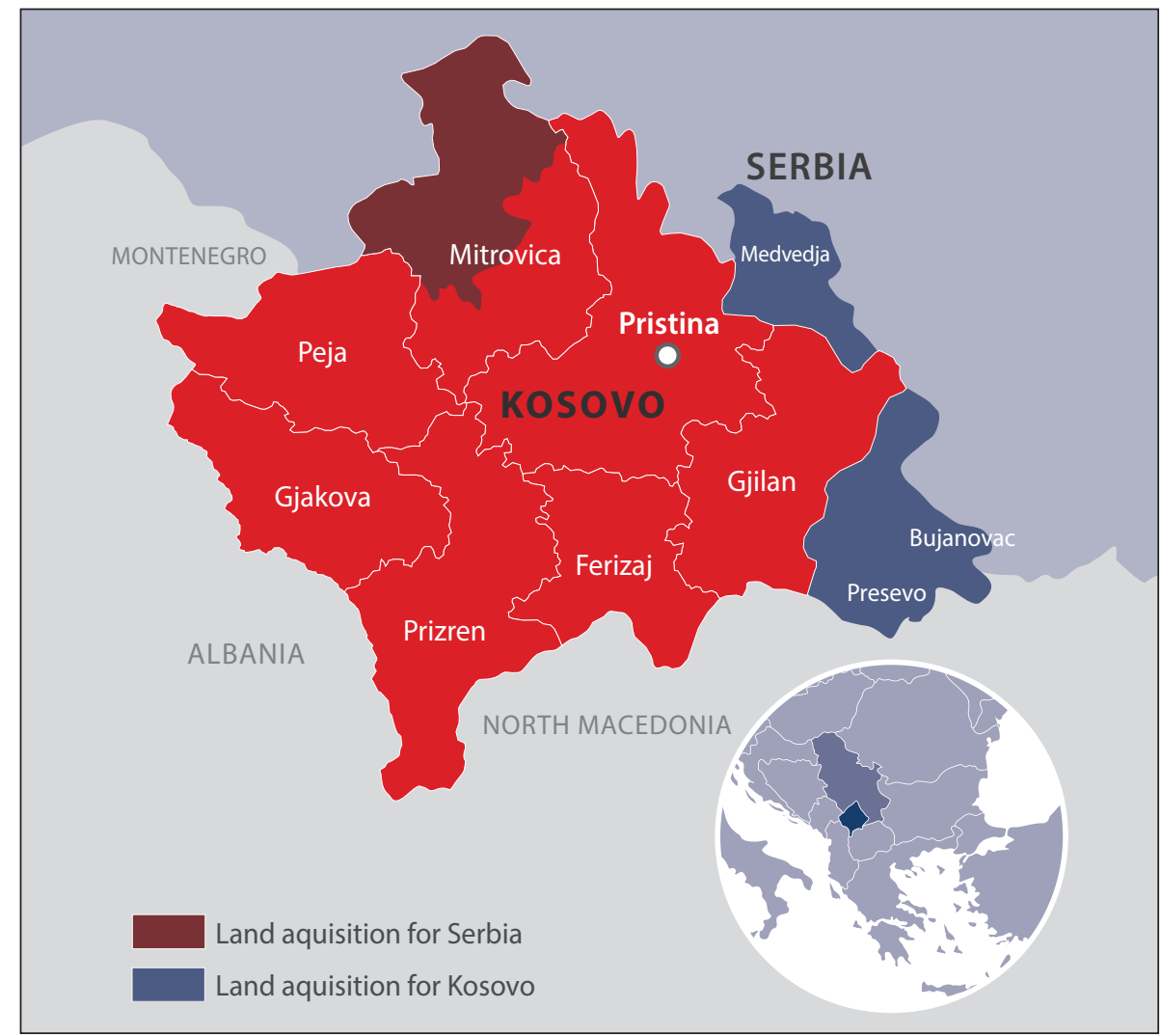

Czech Republic that was finalized in 1997. Following the "velvet divorce" that took place in January 1993, the erstwhile federal partners formed a commission to delineate the border between the two countries and manage minor territorial swaps of disputed areas. ${ }^{17}$ Although the process did result in controversies and slight problems, the land exchange was successful and the accession of the two countries into the Schengen Area marked an end to this peaceful process of territorial rearrangement.

The decolonization of India is probably one of the most violent breakups of a country where millions of people lost their lives and were forced into exodus. India fought at least four wars against Pakistan over the disputed Kashmir region. However, after the creation of independent Bangladesh in 1971, New Delhi was able to establish diplomatic relations with the government in Dacca and in 1974, the first agreement on a territorial exchange was signed. ${ }^{18}$ In 2015, the two countries finalized this protracted diplomatic effort and the exchange of enclaves on both sides was finalized and realized in a peaceful atmosphere. By contrast, it is hard to imagine a settlement of the dispute between Israelis and Palestinians because, among other reasons, both of them lay claim 
to the sacred city of Jerusalem. Territorial exchanges where Israel would cede a part of its mainland and the Palestinian authorities would recognize some of the Jewish settlements in the West Bank have been proposed in peace plans initiatives and debates, but, at the time of this writing (November 2018), there is no agreement in sight. In an article for Foreign Affairs in 1997, Radha Kumar warns, "Although described as the lesser of two evils, the partitions in Cyprus, India, Palestine, and Ireland, rather than separating irreconcilable ethnic groups, fomented further violence and forced mass migration." ${ }^{19}$

\section{Kosovo-Serbia Territorial Exchange: Timing, Extent, and International Reactions}

Many analysts, decision makers, and researchers have questioned the rationale and timing of the current proposal for territorial exchange. There are several reasons why Aleksandar Vučić decided to reintroduce this bid in the summer of 2018. Most importantly, the position of Serbia on the international scene has improved in the last couple of years. Serbia has managed to attract foreign investments and the Serbian president has advocated the settlement of disputes with neighboring countries. In addition, since June 2017, Serbia's government has been headed by a lesbian prime minister -Ana Brnabić- something which has been welcomed in Western capitals. On the other hand, Kosovo has been struggling internally and externally. Some countries, specifically
It appears that Serbia wants

to take control of northern

Kosovo without actually

ceding any land in exchange,

to insist that Kosovo is

nothing more than an errant

autonomous province of

Serbia, and to deny Kosovo

any right to an armed force of

its own

Burundi, Liberia, and Papua New Guinea, retracted their recognition of Kosovo's independence and statehood following the emergence of the report on organ trafficking in Kosovo and the alleged involvement of the KLA's top leaders, which tarnished the narrative of Kosovo's struggle for independence. In addition, approximately 300 Albanians from Kosovo left the country and joined terrorist formations (such as ISIS) which fight against the regime of Syrian dictator Bashar al-Assad.

The internal situation of the EU is quite precarious and complicated. The rise of nativist movements and the surge of right wing parties have sent shockwaves through many pan-European organizations, including the EU. For many years, the German government and its Chancellor Angela Merkel have played a pivotal role in European politics. Germany's controversial decision to welcome 
Serbian recognition of Kosovo

as a sovereign country,

followed by an exchange

of ambassadors - whether

purchased with an exchange

of territory or not- would be a

factor for stability more than a million migrants in 2015 has had a very negative impact on the political cohesion of the EU. Specifically, several countries of Central Europe have stubbornly opposed immigration from developing countries, and the German idea of compulsory relocation of the migrants among the EU member states has further exacerbated the rifts between Berlin and Warsaw, Budapest, Vienna, Prague, and other capitals. The victory of the Brexit campaign and the triumph of anti-immigration parties in Italy have further weakened the position of Germany where immigration is concerned, and presently Chancellor Merkel has very few allies within the EU that sympathize with Germany's critical view regarding the proposed territorial exchange between Serbia and Kosovo.

The Western Balkan states have reacted negatively to the possible territorial exchange. Representatives of Croatia, Montenegro, North Macedonia, and Bosnia and Herzegovina have expressed their opposition to the project, fearing that it might create problems in their countries. In this regard, North Macedonia and Bosnia and Herzegovina are in the most precarious positions. Skopje fears that a change in the Serbian-Kosovar border might send shockwaves into North Macedonia and reignite secessionist tendencies among the Albanian community there, which represents about 25 percent of the total population. North Macedonia has worked very hard to regain the trust of its Albanians after the Albanian insurgency that rocked the country in $2001 .^{20}$ In June 2018, Macedonian Prime Minister Zoran Zaev signed a historic agreement with his Greek counterpart Alexis Tsipras that put an end to the "name dispute" between the two countries. Bosnia and Herzegovina is also quite anxious about the relations between Serbia and Kosovo. The President of the Republic of Srpska (RS), Milorad Dodik, has repeatedly stated that Bosnia is an artificial country and that the RS should secede from Bosnia. Considering the fact that this entity covers 49 percent of the total territory of the country and that Dodik maintains cordial relations with Russia, even calling in October 2018 for Bosnian recognition of Russia's annexation of Ukrainian Crimea, ${ }^{21}$ it is no surprise that the government in Sarajevo has registered its firm opposition to the notion of territorial exchange between Kosovo and Serbia. Politicians of the governing coalition in Montenegro have also expressed negative attitudes towards this idea. Albanians form the majority of the population in the coastal city of Ulcinj and the mountainous swath of borderland between Montenegro and Albania is 
also inhabited by an Albanian community. Thus, it is not a surprise that Podgorica opposes this project.

\section{The Uncertainty of a Western Balkan Territorial Exchange}

North Kosovo encompasses a territory of approximately $1,000 \mathrm{~km}^{2}$ and is inhabited by roughly 80,000 people, around 90 percent of whom are ethnic Serbs. In all four municipalities of the region, Serbs form a majority of the population. On the other hand, the Presevo Valley has a territory of circa $725 \mathrm{~km}^{2}$ and an estimated population of 68,000 people. Albanians are the majority in Presevo and Bujanovac, while Serbs form the bulk of the population in Medvedja. ${ }^{22}$ Thus, the territories that are taken into consideration in the land exchange scheme are comparable in size and population. Whereas north Kosovo is very ethnically homogenous, the Presevo Valley is more heterogeneous, with Bujanovac, for example, inhabited by a sizeable Roma population.

The main incentive for both Serbia and Kosovo to come to an agreement on these territories is the understanding that this is a prerequisite for admission to the European Union. ${ }^{23}$ Beyond that, Kosovo has a strong interest in gaining diplomatic recognition from Serbia, which so far has refused to recognize the new country as anything other than an alienated part of Serbia. While President Vučić has made statements which have been interpreted as opening the door to such recognition, Serbia's Prime
Minister, Ana Brnabić responded to a question in October 2018 by saying, "I think this is the year we will recognize Kosovo for what it is -the autonomous province of the Republic of Serbia. It's not an open question, absolutely not." ${ }^{24}$ One cannot assume, however, that this is the Serbian government's final position. Politicians routinely make statements for specific audiences and Brnabićs statement may have been intended to re-assure Serbs, rather than to emphasize Serbian intransigence or to play "bad cop" against Vučić's "good cop" as part of a negotiating strategy. But it is worth noting that the official website of the Serbian Ministry of Foreign Affairs still refers to "Kosovo and Metohija" (the Serbian name rejected by Albanians) as a "Province;" 25 the official viewpoint of the Serbian government, thus, does not even concede that there is a dispute about the status of Kosovo, let alone that it declared its independence in 2008. Moreover, Balkan Insight reported in October 2018 that "Serbia's Prime Minister, Ana Brnabić, told the media recently that negotiations on the three municipalities [in the Presevo valley] were not an option, and Kosovo officials should not keep mentioning them." ${ }^{26}$ In addition, one must factor in Vučić's criticism in an interview with Serbian $T V$ in November of Kosovo's plans to set up an army. ${ }^{27}$ If these statements by the president and prime minister of Serbia may be taken at face value, then it appears that Serbia wants to take control of northern Kosovo without actually ceding any land in exchange, to insist that Kosovo is nothing more 
than an errant autonomous province of Serbia, and to deny Kosovo any right to an armed force of its own. If this is the negotiating position of the Serbian government, then Kosovo's President Hashim Thaçi may be fooling himself by thinking that the negotiations reflect anything more than European Union pressure. Add to that Thaçi's description of Serbian behavior in the talks as "aggressive and arrogant" 28 and the announcement by Kosovo's Prime Minister on November 21, 2018 that his country would increase tariffs on Serbian imports immediately from 10 percent to 100 percent, ${ }^{29}$ and it seems obvious that the establishment of anything resembling a harmonious agreement is a long way off. Of course, Serbian recognition of Kosovo as a sovereign country, followed by an exchange of ambassadors -whether purchased with an exchange of territory or notwould be a factor for stability. But, at the time of this writing, it is hard for us to believe that these negotiations will be successful without continued international pressure and the introduction of new incentives for the two states to come to an agreement.

\section{Endnotes}

1. Bill Clinton, "Kosovo Deserves Our Congratulations and Continued Support," President Bill Clinton Official Web Page, (February 16, 2018), retrieved October 11, 2018, from https://www.facebook. com/notes/president-bill-clinton/kosovo-deserves-our-congratulations-and-continued-support/10156197081729866/.

2. Die Morina, "Calls Grow in Kosovo for 'Border Correction' Protests," BIRN, (August 31, 2018), retrieved from http://www.balkaninsight.com/en/ article/kosovo-vetevendosje-warns-protests-fornext-week-08-31-2018.
3. Maja Zivanovic, "Serbians in Favour of Belgrade-Pristina Talks: Survey," Balkan Insight, (November 2, 2018), retrieved from http://www. balkaninsight.com/en/article/serbs-in-favour-ofbelgrade-pristina-talks-survey-11-02-2018.

4. "U.S., Germany at Odds Over Serbia-Kosovo Land Swap," Wall Street Journal, (August 31, 2018), retrieved from https://www.wsj.com/articles/us-germany-at-odds-over-serbia-kosovo-landswap-1535729377; Jacopo Barigazzi, "Mogherini Defends Kosovo Border Change Talks," Politico, (August 31, 2018), retrieved September 1, 2018, from https://www.politico.eu/article/ federica-mogherini-kosovo-serbia-defends-border-change-talks/.

5. For a comprehensive analysis of the break-up of Yugoslavia see, Sabrina Petra Ramet, Balkan Babel: The Disintegration of Yugoslavia: From the Death of Tito to the Fall of Milošević, $4^{\text {th }}$ Edition, (Boulder: Westview Press, 2002).

6. See, James Pettifer, The Kosova Liberation Army: Underground War to Balkan Insurgency, 1948-2001, (London: Hurst, 2014).

7. David Rohde, "Crisis in the Balkans: In Macedonia, More Refugees Are Allowed to Flee, but Not All of Them," The New York Times, (April 16, 1999), retrieved from https://www.nytimes.com/1999/ 04/16/world/crisis-balkans-macedonia-more-refugees-are-allowed-flee-but-not-all-them.html.

8. This move was opposed by Russia and China and thus, it did not get the green light from the Security Council of the UN. See, Heike Krieger (ed.), The Kosovo Conflict and International Law: An Analytical Documentation 1974-1999, (Cambridge: Cambridge University Press, 2012).

9. "Under Orders: War Crimes in Kosovo," Human Rights Watch, (October 26, 2001), retrieved from https://www.hrw.org/report/2001/10/26/underorders-war-crimes-kosovo.

10. "North Kosovo: Dual Sovereignty in Practice," International Crisis Group, (March 14, 2011), retrieved from https://www.crisisgroup.org/ europe-central-asia/balkans/kosovo/north-kosovo-dual-sovereignty-practice.

11. See, "Failure to Protect: Anti-Minority Violence in Kosovo, March 2004," Human Rights Watch, (July 25, 2004), retrieved October 11, 2018, from https: //www.hrw.org/report/2004/07/25/failure-protect/anti-minority-violence-kosovo-march-2004.

12. "Inhuman Treatment of People and Illicit Trafficking in Human Organs in Kosovo," Parliamentary Assembly: Council of Europe, (December 12, 2010), retrieved from http://www.assembly.coe. 
int/nw/xml/XRef/Xref-DocDetails-EN.asp?fileid= 12608 \& wrqid $=0$ \& ref $=3446$ \&lang $=E N$.

13. Piotr Smolar, "Serbia and Kosovo Sign Historic Agreement," The Guardian, (April 30, 2013), retrieved from https://www.theguardian.com/ world/2013/apr/30/serbia-kosovo-historicagreement-brussels.

14. "Exodus from Kosovo: Why Thousands Have Left the Balkans," The Telegraph, (February 21, 2015), retrieved from https://www.telegraph.co. uk/news/worldnews/europe/kosovo/11426805/ Exodus-from-Kosovo-Why-thousands-have-leftthe-Balkans.html.

15. Philip G. Roeder, "Soviet Federalism and Ethnic Mobilization," World Politics, Vol. 43, No. 2 (January 1991), p. 197.

16. See, Thomas de Waal, Black Garden: Armenia and Azerbaijan through Peace and War, (New York: NYU Press, 2013).

17. "Sdělení Ministerstva Zahraničních Věcí o Sjednání Smlouvy Mezi Českou Republikou a Slovenskou Republikou o Generelním Yymezení Společných Státních Hranic," Zákony pro lidi.cz, (May 3, 1993), retrieved October 11, 2018, from https://www.zakonyprolidi.cz/cs/1993-229.

18. Willem van Schendel, "Stateless in South Asia: The Making of the India-Bangladesh Enclaves," The Journal of Asian Studies, Vol. 64, No. 1 (2002), pp. 115-147.

19. Radha Kumar, "The Troubled History of Partition," Foreign Affairs, Vol. 76, No. 1 (January/February 1997), p. 24.

20. See, Dejan Marolov, "Understanding the Ohrid Framework Agreement," in Sabrina P. Ramet, Ola Listhaug, and Albert Simkus (eds.), Civic and Uncivic Values in Macedonia: Value Transformation, Education, and Media, (Basingstoke: Palgrave Macmillan, 2013).

21. Mladen Lakic, "Bosnia Should Recognise Crimea as Russian, Says Dodik," Balkan Insight, (October 9, 2018), retrieved October 11, 2018, from http://www.balkaninsight.com/en/article/ crimes-is-part-of-russia-dodik-says-10-09-2018.
22. Albanians and Serbs have boycotted official censuses; thus, these statistics should be treated with caution.

23. David Chazan, "Kosovo President Says No Ethnic Land Swap as Serbia Peace Deal Stalls," The Telegraph, (November 14, 2018), retrieved November 21, 2018, from https://www.telegraph. co.uk/news/2018/11/14/kosovo-president-saysno-ethnic-land-swap-serbia-peace-deal/.

24. As quoted in, "Chance for Serbia Deal Must Be Seized, Kosovo Says," Voice of America, (October 2, 2018), retrieved November 21, 2018, from https:// www.voanews.com/a/chance-for-serbia-dealmust-be-seized-kosovo-says/4596825.html. See also, "Glišić: Kosovo deo Našeg Identiteta," Danas, (November 16, 2018), retrieved November 22, 2018, from https://www.danas.rs/politika/glisickosovo-deo-naseg-identiteta/.

25. "Minister Dacic and UN Secretary-General Discuss Situation in Kosovo and Metohija and Importance of the Role of UNMIK," Ministry of Foreign Affairs of the Republic of Serbia, (November 14, 2018), retrieved November 22, 2018, from http://www.mfa.gov.rs/en/press-service/statements/18335-minister-dacic-and-un-secretarygeneral-discuss-situation-in-kosovo-and-metohija-and-importance-of-the-role-of-unmik.

26. Maja Zivanovic, "Borders Not Off-Limits in Serbia-Kosovo Talks," Balkan Insight, (October 25, 2018), retrieved November 21, 2018, from http:// www.balkaninsight.com/en/article/borders-notoff-limits-in-serbia-kosovo-talks-10-19-2018.

27. "EU Foreign Policy Chief Urges Serbia, Kosovo Resolve Ties," New York Times, (November 8, 2018), retrieved November 21, 2018, from https://www. nytimes.com/aponline/2018/11/08/world/europe/ap-eu-eu-kosovo.html.

28. "EU Foreign Policy Chief Urges Serbia, Kosovo Resolve Ties."

29. "Hodžaj: Kosovo Uvelo Carine od 100 Odsto Srbiji i BiH," Danas, (November 21, 2018), retrieved November 22, 2018, from https://www.danas.rs/ ekonomija/hodzaj-carine-na-srpsku-robu-100odsto/. 


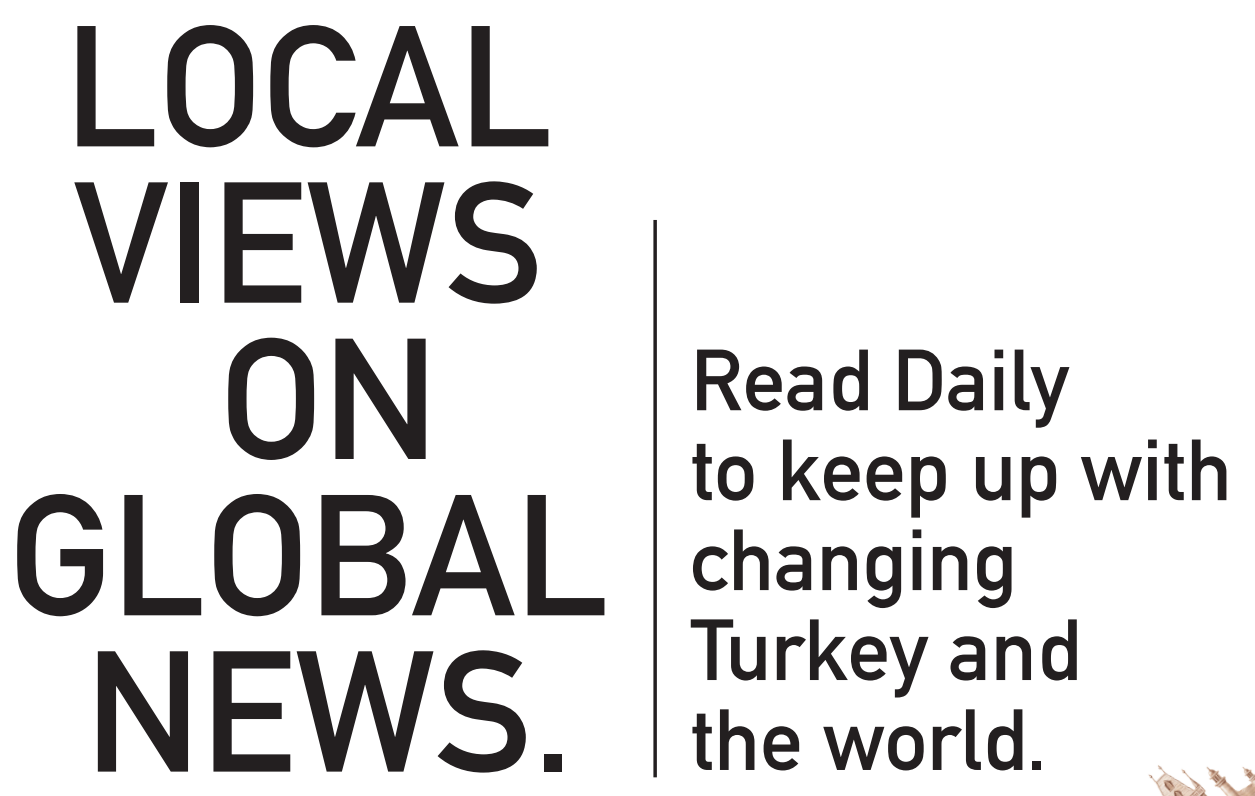

Read Daily to keep up with changing Turkey and the world.

\section{DAILY 马AВAH}

